\title{
IMPLEMENTING AUTHENTIC READING MATERIAL TO IMPROVE READING COMPREHENSION SKILL OF THE TENTH GRADE STUDENTS AT SMK 17 AGUTUS 1945 MUNCAR BANYUWANGI
}

\author{
Ridwan \\ Institut Agama Islam Darussalam Blokagung Banyuwangi \\ Email: mbahjohn742@gmail.com
}

\begin{abstract}
This study aims to improve students' reading skill by authentic reading material.Classroom action reseacrh (CAR) aims to discover teaching and learning strategies that match the style of the learner and to overcome teacher problems in getting the right techniques in teaching. Research hold in SMK 17 August 1945 Muncar Banyuwangi on 27 students of class X APHI done in two cycles with stages of planning, implementing, observing, and reflecting. Insruments used for data collection are observation sheets, questionnaires and student opinions about the authentic reading material. The teaching and learning procedure is cleaved into three steps; preactivity, main activity, and post activity. Researcher found that the application of authentic reading material can improve student's reading skills.
\end{abstract}

\section{Keywords : Reading Comprehension Skill, Authentic Reading Material}

\begin{abstract}
Abstrak
Penilitian ini bertujuan untuk meningkatkan keterampilan membacaa siswa dengan menerapkan bahan membaca yang autentik. Penelitian tindakan kelas (PTK) bertujuan untuk menemukan strategi belajar mengajar yang sesuai dengan gaya pengajar dan untuk memecahkan masalah guru dalam menemukan teknik yang tepat dalam mengajar. Penelitian yang dilakukan di smk 17 Agustus 1945 Muncar Banyuwangi pada 27 siswa kelas X APH1 yang dilakukan dalam dua siklus dengan tahapan perencanaan, pelaksanaan, observasi, dan refleksi. Instrumen yang digunakan untuk pengumpulan data adalah lembar observasi, kuesioner, dan pendapat siswa tentang bahan bacaan autentik untuk kemampuan pemahaman membaca. Prosedur belajar mengajar dibagi menjadi tiga langkah ; pra aktivitas, aktivitas utama, dan aktivitas pasca. Peneliti menemukan bahwa penerapan bahan membaca yang autentik dapat meningkatkan keterampilan pemahaman membaca siswa.
\end{abstract}

\section{Kata Kunci : Ketrampilan Pemahaman Membaca, Bahan Membaca Yang Autentik}




\section{A. Introduction}

English is applied in all aspects of life including educations. In indonesia English is instructedon teaching at elementary school, junior and senior high school as a compulsory subject. There are four language skills that should be taught to the student namely : listening, reading, and writing. Reading as one of the four language skills is taught to the student because it is a way of gaining knowledge and informations. By reading, someone can unlock the window of knowledge and informations. Without any comprehension the student will get nothing. In relation to the idea, Mc whorter (1986:90) says that comprehension involves comprehending words, setences, paragraphs, and texts.

Based on the previous description The writer concludes that The students of SMK 17 Agustus 1945 Muncar Banyuwangi especially the tenth grade had problems in reading, especially in comprehending the English text. This problem can also be proved based on their scores in reading test in the preliminary observation. Their scores are under the standard minimal. The standard minimal score (KKM) of reading aspect is 70 , but the fact is there are several students who get score under 70. It means that they got low score of reading test and still far from the target.Their problem of comprehension were usually caused by their incapability in understanding the meaning of the difficult word, in comprehending ideas or messages from one paragraph to the next paragraph, or even they lack of vocabularies. The method which used by the English teacher, question and answer method still did not make the students comprehend the text well. So, it is quite essential to improve their ability in comprehending the english text.

The problem above indicated that it is important to give the students the same amount of change in exercising their reading skill and pay more attention to create agood learning atmosphere through Authentich Reading Material technique. It will help the students' not only comprehending the passage, but also helping them to memorize the passage that they have read.Student apply what thay have learn in real life situation. As a result, student find that reading lesson in school is not interesting and irrelevant to their daily life. So they tend to be lack of attention, passivity. 'off-task' attitudies, and having destructive forms of behavior in class (Cheung, 2001:57). Regarding the teaching of reading process, the teacher 
should give solution of difficulties in comprehending text. The purpose is to make the students able to comprehend the text easily by using appropriate reading technique in any type of text.

1. Research Problem and Research Objective

Based on the background of the research above, the research was formulated as follows :how can the implementation of authentich reading material improve reading skill of the tenth grade students at SMK 17 Agustus 1945 Muncar Banyuwangi?. Referring to the formulation of the problem mentioned above, the object of the study is to describe how authentich reading material can improve the reading skill of the tenth grade students of SMK 17 Agustus 1945 Muncar Banyuwangi.

2. Reading Comprehension Achievement

Reading comprehension is concerned with the readers' ability to understand reading texts. Grelet (1996:8) states that reading is an active constant process of predicting, checking and asking one self question. Hornby (1987:698) defines reading comprehension is to understand something written or printed. It can also broadly deffined as accessing meaning trough' printed word (Oakhill and Beard, 1999:109). Simanjutak (1988:4) confirms that the first point to be made about the reading process is reading comprehension. Further, he says that comprehension is always directed and controlled by the needs and purposes of individual. He also says that good comprehension means understanding general ideas and specific facts in the text in order to get the message of the text. Meanwhile, skill can be defined as a result of doing something.

\section{B. Literature Review}

1. Word Comprehension and Sentence Comprehension

It is basically important in reading comprehension to understand word meaning, because it is impossible for the students to comprehend the text or the material without understanding the meaning of the word (Burns,1984:161). Sometimes, the student find unfamiliar word. Here, they must guess or decode the meaning of the word. Grellet (1996:7) states that the students should be taught to use what they know how to understand unknown element. Mc Whorter (1986:85) 
defines a sentence as a group of word that a complete thought or idea. In order to understand the sentence, the reader cannot understand the meaning of some word constructed in the sentence that to understand the meaning of word by words. The readers also should know the way how to connect idea within a sentence.

2. Identifying Key Idea

Every sentence expresses at least one key idea, or basic message (Mc Whorter 1989:86). This key idea is made up of two parts, a simple subject and simple predicate. The simple subject, usually a noun, identifies a person or object the sentence is about. The main part of the predicate (the simple predicate) is a verb, which tell what the person or object is doing or has done. Further, there are two questions considered to find the key ideas : (1)who or what is the sentence about? (2) what is happenning in the sentence? In other word, the first question is asking the subject and the second sentence is asking the verb.

3. Locating Details

After knowing the way how to identify the key idea, the next step in understanding a sentence is to see how the details effect its meaning. Mc Whorter (1989:88) confirms that most detail either add to change the meaning of the key idea. Usually they answer such a question about the subject or verb such as what, where, which, when, how, or why.

4. Combining Idea Into A Sentence and Reading Complicated Sentence

A sentence may express more than one idea (Mc Whorter, 1989:89). Two or more closely related ideas can be combined into one sentence. There are two ways to combine ideas into a sentence: 1 . The two ideas may be connected with a comma and conecting word such as and, but, or, nor, so, for, yet.2.Two idea may also be joined using semicolon.Furthermore, it is very important for the reader to be aware of all key idea when they read a sentence that expresses more than one idea.

Many sentence in a text might be long and complicated (Mc Whorter, 1989:93). Sometimes people think that a sentence is long and complicated because it is not only made in chronological order or by splitting the subject and the verb, but also because it uses pronouns. When reading sentence that are made 
in chronological order, reader should stop and establish the correct order of event before continuing to read.

A sentence may also be made by splitting the subject and the verb, additional information is placed between them, and the sentence become more difficult to read. For this type of sentence, the readers are forced to keep the subject in mind while they read the additional information until they reach the action or the verb of the sentennce. When they have already reached the verb they should be sure to connect it with the subject.

\section{Paragraph Comprehension and Identifying Topic Sentence}

Carino (1991:145) defines paragraph as relatively short piece of writing or a verry limited topic that can stand alone but usually is a part of an eassy. According to Wingersky,et.al (1999:24) a paragraph is a group of related sentence that support one main idea. So, in order to be able to comprehend a paragraph, students as readers need to comprehend all sentence.Further, a paragraph consists of three part (Wingersky et.al, 1999:31) those three part are a topic sentence, supporting sentences, and a concluding sentence. Identifying topic sentence, supporting sentence, and concluding sentence will be discussed in more detail as follow.

Identifying topic sentence help the reader understand the main idea of a paragraph, Mc Whorter (1989:104) says that the topic is one thing the paragraph is about. Therefore, the topic is a subject in the entire paragraph.

6. Finding Main Idea and Recognizing Supporting Details

Main idea of paragraph is the most important idea because it explains or supports the idea of the whole paragraph. Wood (1996:196) states that the author uses supporting details in order to make ideas clear, interest and memorable.

7. Identifying the Concluding Sentence

Conclusion is verry important to the readers bicause it signals the end of the paragraph and remains them the paragraph points of the paragraph. Besides, a concluding sentence has two main purposes, it serves a final comment of the writer about the topic and leaves the reader with the most important idea to think about (Muhyidin, 1988:15). 
C. Method

1. Research Design

This research was intented to increase the tenth grade students reading comprehension skill by using authentic reading materials. In accordance with the problems faced in SMK 17 Agustus 1945 Muncar Banyuwangi, a classroom action research was conducted to solve the problem. This classroom action research was conducted in two cycles in which each cycle covered preparation of the action, implementation of the action, classroom observation, and reflection of the action. If the result of reading comprehension test in the first cycle could not achieve at least $70 \%$ of the total student who got score at least 65 or in fair category, the action were continued to second cycle The student design of this action research was illustrated in the following diagram:

Picture 1 The Model of Classroom Action Research

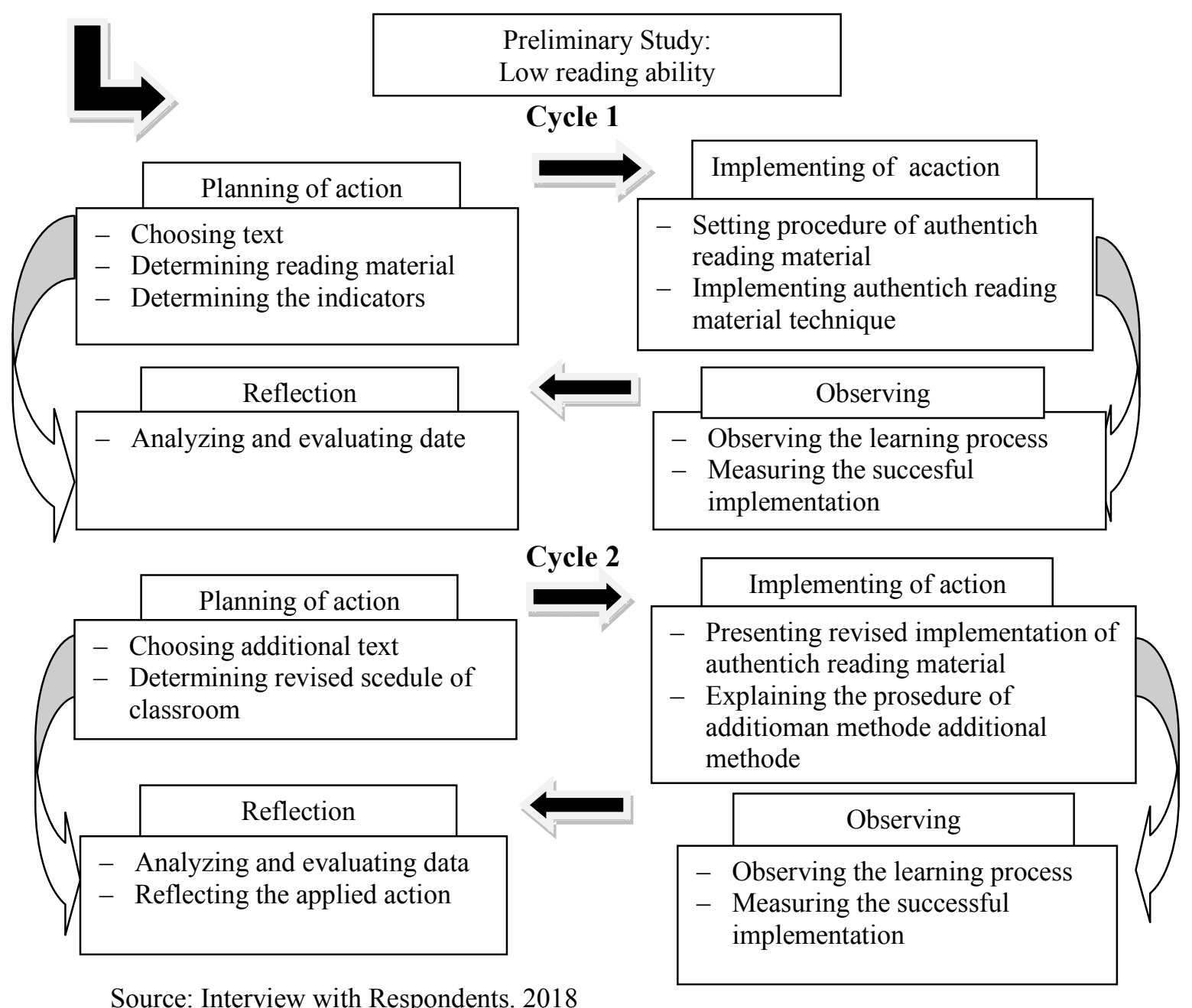

Jurnal Darussalam; Jurnal Pendidikan, Komunikasi dan Pemikiran Hukum Islam Vol. XI, No 1:1-17. September 2019. ISSN: 1978-4767 (Cetak), ISSN: 2549-4171(Online) Terakreditasi Nasional. SK. No.21/E/KPT/2018 
2. subject

The subjects of the study are tenth grade students of SMK 17 August 1945 Muncar Banyuwangi.

3. Procedure

This study follows the following steps:

a. Preliminary study: identifying, analysing, formulating, the problem, and collaborating between the researcher and teacher.

b. Planning the action: preparing the teaching strategy, determining the lesson plan, preparing instructional material and relevant media, preparing the criteria of success

c. Implementing the action: the researcher is as practitioner teacher teach reading by using the lesson plan, interview guide, evaluation, reflection, and analysis the collected data, determining whether the action is successful or unsuccessful.

d. Observation: observing the teaching and learning process, collecting the data, observation forms, observation sheet, and field notes.

\section{Preparing Teaching Strategy}

The teaching strategy that will be used is "Authentich technique". It emphasizes in practicing the students' reading skill. In general, the techniques which are carried out in the research contain the following steps: 1) Introduces What is authentich reading technique and the rules of summarizing. 2) Students are given some english text and should answer the question in orally or written based on the text given. 3) Practice and apply authentich reading technique in their reading activity, 4) Question time. In the preparing teaching strategy, first the researcher observed the technique of teaching learning process which is used by the English teacher in English teaching learning process. Second, the researcher formulated the teaching strategy that will be conducted in teaching learning process as the effort to improve the students reading comprehension by using authentich reading technique. It means that the teaching strategy of this classroom action research is the use of authentich reading as the media to teach reading comprehension. third, the researcher gave the the english text to the students. fourth, researcher asks the students to make summary of the passage by 
determining the main idea of each paragraph. Fifth, Students are required to explain what is the text about? After summirising the passage by determining the main idea of each paragraph ofcourse students will be able to comprehend the text well.

a. Pre activity, In pre activity the teacher motivates students in order to get the students interest in the class. Engaging students is important for learning process. The teacher asks some questions based on the ability of their reading. Here the teacher also gives some written questions of english texts in order to know how far students understand and involve in teaching and learning process.

b. Main activity, the teacher informs to the students to objectives of the lesson in order to know what they will get after the lesson, the teacher explaines the lesson to provide information that helps to explain the aspects of the activity after students have been provided opportunuties to explore and inquire. It may be necessary to provide science content information or expected result or conclussions.

c. Post activity for the session final expression is the same importance as initial one. Teacher should end the presentation with deceive closing.

\section{The Criteria of Success}

To decide the criteria of success, the researcher used the criteria to see whether the implementation of authentich reading technique in teaching reading skill had succeded or failed. The standard minimal score of reading aspect is 70 , so the score of reading comprehension should be 70 as well improved.

\section{Observation}

The researcher used the checklist guide which contains the indicators being observed to monitor the students activities during the process of teaching and learning. The observation sheet is used to know the students difficulties in reading comprehension and to know the media which is used in teaching learning process whether it has been able to increase the students ability in comprehending the text or not. In observation stage, all the data were collected and actions were observed. The observer used observation sheets to observe the teacher and students activities. 


\section{Description of reading authentic material Implementation}

This study was accomplised in two cycles. Further discussion of each cycle is presented in the following.

\section{Meeting 1}

The first meeting was conducted on 12nd of February 2016 at 07.00 a.m to 08.30 a.m. The activity of first meeting was giving explanation about topic on reading test, implementing reading test through authentich reading material. In this meeting the researcher started with explaining about reading, how to comprehend the text by using authentich reading material which contains: analizing main idea, topic and controling idea in each paragraph. Then the students were given a text to be answered and to be comprehended by using authentich reading material. And after that the theacher asked the students to submit the test paper and asked them to make review of the text.

\section{Meeting 2}

The second meeting was conducted on $14^{\text {th }}$ of February, 2016 at 08.30 a.m to 10.00 a.m. the activity of second meeting was used for asking students' response about reading test. The Implementation was as follows;

a. Pre-activity and Main activity

The teaching learning process started with greeting and checking the students' presence. The researcher reminded the students about the importance of English especially reading. And then gave them some leading questions, it is like "What do you know about recount text?" and then the researcher explained more details about the kinds of text woul be discussed and then gave them some recount text to be answered as a test.

The researcher discussed the previous test and gave feedback of the test. And after that the researcher gave another text of recount to be comprehended. In this activity the researcher could be more understand about the students' development in reading comprehension based on the result the test.

b. Post activity

After discussing with the teacher were observing the students' reading test, the teacher made some notes of cases faced by the students related to the students' reading comprehension skill. 


\section{Reflection}

After discussing with the teacher, the researcher made some conclussion dealing with the implementation authentich reading material to improve the students' reading skill. They had observed that the students have enthusiasm in their activity. Most of them seemed to be cleverer to comprehend the text and did the exercises well. So the teacher could say that the students were motivated in reading and they are able to answer the questions of the text. Eventhough, the next cycle is needed to be done because it did not fulfil the criteria of succes. As the fact that the average score of students' achievement was $57.5 \%$. It is lower than the minimum criteria successful of 70 .

\section{The Revision of Strategy Implemented in Cycle 1}

In this cycle, the researcher revised the lesson plan. They revised the result of their reading test in the first cycle.The weakness of the first cycle was low of understanding's students in comprehending the text, so the result of the test was still low of standard minimal score that is 65 . So it was still needed to do research for the next cycle. The revision of learning strategy on the second cycle was placed on the Pre reading. The teacher explained the lesson material and gave authentich reading material. This strategy is recommended by English teacher when the teacher wants to make a variation in teaching learning.

After giving the text, The students sat on their seat and begun to read the text and answered some questions of the text. After finishing their activity students should submit the test on the teacher desk and the teacher asked them to make review of the text they had read.

\section{Cycle 2}

The second cycle was done February $23^{\text {rd }}, 2016$ and February $24^{\text {th }}, 2016$. The stages done in the second cycle were the same as the ones in the first cycle, namely, prepration of the action, implementation of the action, observation and reflection. Prepration of the action involved the activies of preparing the revised plan discussed with the English teacher. It was revised based on the weakness found in the first cycle. The implementation of the action in the third meeting was done based on lesson 3 and the fourth meeting was based on the lesson plan 4 . Lesson plan 3 and 4 for cycle 2 are enclosed on appendik 7 and 8. 
Process evaluation through observation checklist was done during the reading comprehension teaching learning process by applying authentic reading materials in each meeting in cycle 2 . At the end of the second cycle, the reading comprehension test was also administered to measure the students reading comprehension skill.

\section{Implementation of Action}

In implementation stage, the researcher applied the technique in teaching reading. The implementation of cycle 2 , the researcher conducted the teaching learning in the classroom for two times: Meeting 1, The first meeting on the second cycle was conducted on February, $25^{\text {th }} 2016$ at 07.00 a.m to 08.30 a.m. the activity of first meeting was giving explanation about topic on reading test, implementing reading test through authentich reading material. The teacher used familiar topic such as study tour. Beside that the teacher ask to students prepare the first draft in your reading material.

Reading material ask the students' to identify the title of the text, b) Ask the students' to write the detail of reading material, c) Ask the students' to express the main point or the detail of reading material by their own words, d) Quote from the material only to illustrated key points, e) Preserve the balance and proportion of the original work, f) Ask the students' to revise the students' first draft, g) Write the final draft on the paper.

After the students' write the reading material, the teacher gives some question to measure the students' comprehension about the text that have been read. In this case, the question are used to measure the Literal and Inferential Comprehension.

Meeting 2, The second meeting was conducted on February, 27th 2016 at 07.00 a.m to 08.00 a.m. the activity of second meeting was used for asking students' response about reading test 2 . The second meeting was identical with two meetings in ordinary teaching learning process. The implementation of the action was done as bellows:

a. Pre activity, In pre activity the teacher motivates students in order to get the students interest in the class. Engaging students is important for learning process. The teacher asked some questions based on the skill of their reading. 
Here the teacher also gave some written questions of english texts in order to know how far students understand and involve in teaching and learning process.

b. Main activity, the teacher inform to the students to objectives of the lesson in order to know what they will get after the lesson, the teacher explained the lesson to provide information that helps to explain the aspects of the activity after students have been provided opportunuties to explore and inquire. It may be necessary to provide science content information or expected result or conclussions.

c. Post activity for the session final expression is the same importance as initial one. Teacher should end the presentation with deceive closing.

\section{Result}

Observation, In observation stage, all the data are collected and actions are observed the observer used observation sheets to observe the teacher and students activities. Having known the result of observation and the reading comprehension test in cycle 2, it could be stated that the students had better improvement both in their process evaluation $(75 \%$ of the students were actively involved in the reading teaching learning process) and product evaluation (75\% of the students got score at least 65).

The result of the action in the second cycle had achieved the research target. There were $77.7 \%$ of the students who got score at least 65 . Moreover, based on the classroom observation, in third meeting three were $74 \%$ of the students actively involved in the teaching learning process, and in the fourth meeting there were $81.5 \%$ of the students were actively involved during the reading teaching learning process. They asked some questions to the teacher, answered the teachers oral question given performed the task well and they also seemed very enthuasiastic and paid much attention during the reading teaching learning process. Since the actions in cycle 2 had already fulfilled the requirement of the research target; therfore, the actions in cycle two were stopped 


\section{E. Discussion}

The material used in each meeting and the tests were taken form internet. The materials in first cycle were taken form western website and the materials in the second cycle were taken form indonesia website. Based on the result of the reading comprehension skill test, the percentage of the students who got at least 65 increased form $70 \%$ to $77.7 \%$. in addition, the percentage of the student active participation in reading teaching lerning process increased from 66.6 to $81.5 \%$

The following table presents the improvement of the students reading comprehension skill in the first cycle and the second cycle.

Table 1 The Improvment of the Students Reading Comprehension Skill in the Cycle 1 and 2

\begin{tabular}{|l|c|c|c|c|}
\hline \multirow{2}{*}{ Target } & \multicolumn{2}{|c|}{ Cycle 1 } & \multicolumn{2}{c|}{ Cycle 2 } \\
\cline { 2 - 5 } & $\begin{array}{c}\text { Meeting } \\
\mathbf{1}\end{array}$ & $\begin{array}{c}\text { Meeting } \\
\mathbf{2}\end{array}$ & $\begin{array}{c}\text { Meeting } \\
\mathbf{3}\end{array}$ & Meeting 4 \\
\hline $\begin{array}{l}\text { The percentage of the students active } \\
\text { participation in the reading teaching } \\
\text { learning process }\end{array}$ & $\mathbf{5 9 . 2 \%}$ & $\mathbf{6 6 . 6 \%}$ & $\mathbf{7 4 \%}$ & $\mathbf{8 1 . 5 \%}$ \\
\hline $\begin{array}{l}\text { The percentage of the students } \\
\text { reading comprehension skill }\end{array}$ & \multicolumn{2}{|c|}{$\mathbf{7 0 \%}$} & \multicolumn{2}{|c|}{$\mathbf{7 7 . 7 \%}$} \\
\hline
\end{tabular}

Source: Interview with Respondents. 2018

Based on the observation result in cycle 1, there were $59.2 \%$ and $66.6 \%$ of the students actively involved in the teaching learningn process. While in the cycle 2 , the students active participation was $74 \%$ and $81.5 \%$. Futher, the action was considered successful if $75 \%$ of the students were actively involved in the actions, and the students were considered to be actively involved if they fulfilled at least three of the indicators observed. At last, form the result of observation in both cycles, it can be concluded that the percentage of the students who were actively involve in the reading comprehension teaching learning process increased from $65 \%$ to $81.5 \%$. They paid much attention during the reading teaching learning process and eager answered teachers questions during the lesson as well. The students were completed in performing the task on the whiteboard. Besides, they also actively asked question to the teacher related to the reading materials taught. This fact proved that, the application of authentic reading materials could increase the students' active participationin reading teaching learning process using authentic reading materials. 
Based on the observation result in cycle 1 , there were $59.2 \%$ and $66.6 \%$ of the students actively involved in the teaching learning process. While in the cycle 2 , the students active participation was $74 \%$ and $81.5 \%$. Further, the action was consirdered successful if $75 \%$ of the students were actively involved in the actions, and the students were considered to be actively involved if they fulfilled at least three of the indicators observed. At last, from the result of observation in both cycles, it can be concluded that the percentage of the students who were actively involve in the reading comprehension teaching learning process increased from $66.6 \%$ to $81.5 \%$.. This fact proved that, the application of authentic reading materials could increase the students' active participation in reading teaching learning process using authentic reading materials.

Besides, based on the result of reading comprehension skill test in cycle 1 . There were $70 \%$ of the students got score at least 65 . While in the cycle 2 . There were $77.7 \%$ students got score at least 65 . Further, the actions were considered successful if $75 \%$ of the students got score at least 65 . From the result of reading comprehension skill test in both cycles, it can be concluded that the percentage of the students who got 65 increased from 70\%. To $77.7 \%$ It means, the action considered as success because the research had already fulfilled the target requirements.

Finally, the result of this actions research on two cycles proved as follows: The use of authentic reading materials could improve the tenth grade students reading comprehension skill of SMK 17 Agustus 1945 Muncar Banyuwangi.

Table 2 The Improvment of the Students Reading Comprehension Skill in the Cycle 1 and 2

\begin{tabular}{|l|c|c|c|c|}
\hline \multirow{2}{*}{ Target } & \multicolumn{2}{|c|}{ Cycle 1 } & \multicolumn{2}{c|}{ Cycle 2 } \\
\cline { 2 - 5 } & Meeting 1 & Meeting 2 & Meeting 3 & Meeting 4 \\
\hline $\begin{array}{l}\text { The percentage of the students } \\
\text { active participation in the } \\
\text { reading teaching learning } \\
\text { process }\end{array}$ & $\mathbf{5 9 . 2 \%}$ & $\mathbf{6 6 . 6 \%}$ & $\mathbf{7 4 \%}$ & $\mathbf{8 1 . 5 \%}$ \\
\hline $\begin{array}{l}\text { The percentage of the students } \\
\text { reading comprehension skill }\end{array}$ & \multicolumn{2}{|c|}{$\mathbf{7 0 \%}$} & \multicolumn{2}{|c|}{$\mathbf{7 7 . 7 \%}$} \\
\hline
\end{tabular}

Source: Interview with Respondents. 2018 
Based on the observation result in cycle 1 , there were $59.2 \%$ and $66.6 \%$ of the students actively involved in the teaching learningn process. While in the cycle 2 , the students active participation was $74 \%$ and $81.5 \%$. Futher, the action was considered successful if $75 \%$ of the students were actively involved in the actions, and the students were considered to be actively involved if they fulfilled at least three of the indicators observed. At last, form the result of observation in both cycles, it can be concluded that the percentage of the students who were actively involve in the reading comprehension teaching learning process increased from $65 \%$ to $81.5 \%$. Besides, based on the result of reading comprehension skill test in cycle 1 . There were $70 \%$ of the students got score at least 65 . While in the cycle 2 . There were $77.7 \%$ students got score at least 65 . Further, the actions were considered successful if $75 \%$ of the students got score at least 65 . From the result of reading comprehension skill test in both cycles, it can be concluded that the percentage of the students who got 65 increased from $70 \%$. To $77.7 \%$ It means, the action considered as success because the research had already fulfilled the target requirements.

\section{F. Conclusion}

Based on the result of the actions both in two cycle, that is teaching reading by using authentich reading material method, giving exercises by using authentich reading material and giving the reading comprehension test by using authentich reading material to the $\mathrm{X}$ grade students of APH1 at SMK 17 Agustus 1945 Munca rBanyuangi. The use of authentich reading material in these two whole aspect in reading, could improve the students reading comprehension, literal and inferential reading comprehension. The improvement could be seen from the students' mean score of reading comprehension test in the second cycle was better the standard mean score of requirement in this research, that was $77,7 \%$ compared with their mean score of reading comprehension test in the first cycle, that was $70 \%$. Further. Finally, it could be conclude that the use of authentich reading material method could improve the eighth grade students' reading comprehension X grade students of APH1 at SMK 17 Agustus 1945 Muncar Banyuwangi. 
The students' reading skill can be improved through authentich reading material method with these following procedures: 1) take afew minutes to preview the work, at the following: title, subtitle, first and last several paragraph, other item. 2) Read the text for all you can understand the first time through. 3) Go back and reread more carefully the areas you have identified as most important. 4) Take a note on the materials; concentrate on getting down the main ideas and the key supporting points. 5) Prepare the first draft in your summary of reading. Keeping these points such as (a) Identify at the start of the title of reading and author of the work. (b) Do not write an overly detail. (c) Express the main point and key supporting detail in your own words.(d) Quote from the material only to illustrate key points.(e) Preserve the balance and proportion of the original work. (f) Revise your first draft. (g) Write the final draft of the paper.

\section{References}

Rivers, Wilga. 1987. Intractive Language Teaching. Cambridge University Press. Weir, C. J. 1999. Communicative Language Testing. London: Prentice Hall.

Wood, N. V. 1996. Strategies for College Reading and Thinking. New York: McGraw-Hill Inc.

Ali, M. 1998. Penelitian pendidikan prosedur dan strategi. Bandung: P.T Angkasa.

Arikunto, S.1998. Prosedur penelitian: suatu pendekatan praktik. Jakarta: Rineka Cipta.

Guariento, W. And Morley, J. 2001. Text and task Authenticity in the EFL Classroom. In ELT journal vol 55/4 October. Oxford University press P. 343-453.

Harrison. 2003. Keys stage 3 English London:Department for Education and Skills. Available at :http://www.standards.dfes.gov.uk//scondary/keystage3. Accessed on January, $28^{\text {th }} 2008$.

Heaton, J,B 1988. Writing English Language Test. London: Longman

Hornby, A.S. 1995. Oxford Advanced learners' Dictionary of Current English. London: Oxford University Press.

Hughes, A.S. 1989. Testing for Language Teacher. Cambridge: Cambridge University Press.

Kasbolah, E.S. Kashani. 1999. Pnelitian Tindakan Kelas. Jakarta: Ditjen-Dikti

Kustaryo, S. 1980. Reading Techniques for College Students. Jakarta: Department Pendidikan

Berardo, A. S. 2006. The Use of Authentic Material in Teaching of Reading: The reading matrix vol 6 No 2 September. Available at: www.Adobe.com/acrobat. Accesed on January, $19^{\text {th }} 2008$.

BNSP. 2006. Standar Kompetensi \& Kompetensi Dasar Bahasa Inggris. Jakarta: 
Badan Standar Pendidikan Nasional.

Burns, D. 1984. Interactive approaches to second language reading. Cambridge: Cambridge University Press.

Carrell, P. L, J. Devince, and D. E. Eskey. 1995. Interactive Approaches to second Language reading. Cambridge: Cambridge University Press.

Cheung, C K. 2001. The Use of Popular Culture as a Stimulus to Motive Secondary Students English Learning in Hongkong, ELT Journal : 55/1

Depdikbud. 1999. Penyempurnaan/Penyesuaian Kurikulum 1994: Bahasa Inggris SLTP. Jakarta: Depdikbud.

Depdiknas.2004. Kurikulum Berbasis Kompetensi Mata Pelajaran Bahasa Inggris SMP dan MTS. Jakarta: Balitbang.

Elliot, J. 1991. Action Research for Educational Change: Developing Teachers and Teaching. Philadelphia: Open University Press.

Fairbairn, G. J. And Winch, C. 1996. Reading, Writing, and Reasioning: A Guide for Students Second Edition, Buckingdom philadelphia: Open University Press.

Fraenkel, J. R. And Norman E. Wallen. 2000. How to Design and Evaluate Research in Education: New York MCGraw-Hill Comp.

Grellet, F. 1996. Developing Reading Skills: A practice Guide to Reading Comprehension. Cambridge University Press.

Lee, Yuk Winnie C. 1995. Authenticity revisitecd:Text authenticity and Learner authenticity. ELT Jounal vol 49 Dec. 4 XVIX. Oxford: Oxford University Press.Harper Collin Publisher.

Mc, whorther, K. 1986. College Reading and skills. Boston: Little, Brown and Company.

Melvin, B. S. And Stout, D. F. 1987. Motivating Language Learners through Authentic Materials. In Rivers, W.M. Interactive Language Teaching. Cambridge: Cambridge University Press.

Morton, R. 1999. Abstracts as Authentic Material for EAP Classes. ELT Journal vol 53/3 July. Oxford: Oxford University Press.

Muhyidin, T. S. 1988. Writing Paragraph and Essay through Model and Exercises. Jakarta: Department Pendidikan dan Kebudayaan.

Peacock, M. 1997. The Effect of Authentic Materials on the Motivation of ESL Learners. In ELT Journal vol 51/2 April. Oxford University Press.

Rivas, R. M. 1999. Reading in Recent ELT Course Books. ELT Journal 53/1 January. Oxford: Oxford Unversity Press. 